ISSN: 2656-9531

JOURNAL OF LANGUAGE, LITERATURE, AND TEACHING

Vol. 1 No. 3, December 2019, pp. 11 - 23

DOI:https://doi.org/10.35529/jllte.v1i3.11-23

\title{
Interlanguage dalam Belajar Bahasa Arab (Studi Tentang Kesalahan Gramatikal Siswi Pondok Pesantren Muqimussunnah Palembang)
}

\author{
Ayu Desrani \\ Pascasarjana UIN Maulana Malik Ibrahim Malang \\ Malang, Indonesia \\ Email: aydesrani@gmail.com
}

\begin{abstract}
Abstrak
Berbicara tentang bahasa pembelajar yang disebut sebagai bahasantara (interlanguage) merupakan isu utama dalam kajian pemerolehan bahasa kedua atau bahasa sasaran. Dikatakan demikian, karena isu ini berkaitan dengan perkembangan bahasa pembelajar dan sangat berkaitan dengan proses yang dilakukan oleh pembelajar untuk menguasai bahasa sasaran. Oleh karena itu, tujuan Penelitian ini adalah untuk mencari tahu tentang proses kesalahan gramatikal yang terjadi dalam interlanguage. data kesalahan interlanguage siswa dalam penelitian ini didapatkan dari hasil observasi, wawancara serta karangan insya siswa yang diperoleh dari guru bahasa arab di mts pondok pesantren muqimussunnah palembang dari kelas 7-8 yang dipilih secara random. Kemudian data tersebut dianalisis secara kualitatif. Penelitin ini menunjukan bahwa proses interlanguage dalam pembelajaran bahasa Arab terdapat banyak keselahan dalam gramatikal adalah transfer bahasa, overgeneralisasi dan strategi belajar bahasa kedua. Dari ketiga proses tersebut proses kesalahan gramatikal yang paling banyak terjadi yaitu dalam proses transfer bahasa yang mana siswa selalu menggunakan kaidah bahasa pertama untuk berbicara bahasa kedua atau bahasa arab, sedangkan yang kesalahan gramatikal kedua terjadi pada overgeneralisasi yang mana siswa melakukan penyerataan kaidah dalam menggunakan bahasa arab, selanjutnya baru kesalahan gramatikal pada strategi belajar bahasa kedua yaitu siswa cenderung menyederhanakan sistem bahasa kedua.
\end{abstract}

Kata kunci: Interlanguage, Kesalahan Gramatikal, Bahasa Arab 
ISSN: 2656-9531

JOURNAL OF LANGUAGE, LITERATURE, AND TEACHING

Vol. 1 No. 3, December 2019, pp. 11 - 23

DOI:https://doi.org/10.35529/jllte.v1i3.11-23

\begin{abstract}
Talking about the language of the learner referred to as language (interlanguage) is a major issue in the study of obtaining a second language or target language. This issue was related to the development of the learner\&\#39; s language and was very related to the learner's process to master the target language. This study aimed to find out about the grammatical error process that occurs in interlanguage. Interlanguage error data of students in this study were obtained from observations, interviews and essays from students obtained from Arabic language teachers in MTs Pondok Pesantren Muqimussunnah Palembang from grades 7-8 randomly selected. Then the data is analyzed qualitatively. This research shows that the interlanguage process in learning Arabic there are many gaps in grammatical are language transfer, overgeneralization and second language learning strategies. Of the three processes, the most grammatical error process occurs, namely in the process of language transfer where students always use the rules of the first language to speak the second language or Arabic, while the second grammatical error occurs in overgeneralization in which students make the norms in using Arabic, then only grammatical errors in second language learning strategies, namely students tend to simplify the second language system.
\end{abstract}

Keywords: Interlanguage, Grammatical Errors, Learning Arabic

\title{
PENDAHULUAN
}

Dalam proses menguasai bahasa kedua (B2) sebagai bahasa target (BT), pembelajar berusaha untuk membentuk kaidah-kaidah kebahasaan tersendiri. Kaidah itu bukan merupakan kaidah kebahasaan yang telah dikuasainya (bahasa I: BI) dan juga bukan kaidah bahasa target. Kaidah kebahasaan itu merupakan konstruksi kreatif dari masing-masing pembelajar. Kaidah-kaidah kreatif ini hanya bersifat sementara. Kaidah-kaidah inilah yang disebut bahasantara (interlanguage) artinya kaidah di antara bahasa yang telah dikuasainya dan kaidah bahasa target. Gejala bahasantara ditunjukkan oleh adanya penyimpanganpenyimpangan dari norma kebakuan berbahasa yang disebut kesalahan berbahasa. Kesalahan ini terjadi karena pembelajar sulit meninggalkan kaidah-kaidah kebahasaan yang telah dikuasainya. Pembelajar mencoba menggunakan kaidah kebahasaan yang telah dikuasainya untuk diterapkan pada bahasa target(Fauziati \& Maftuhin, 2016). 
ISSN: 2656-9531

JOURNAL OF LANGUAGE, LITERATURE, AND TEACHING

Vol. 1 No. 3, December 2019, pp. 11 - 23

DOI:https://doi.org/10.35529/jllte.v1i3.11-23

\section{西溷圆隆友好学院}

Baradja menyatakan, bahwa pembelajar dalam perjalanannya menuju kepada penguasaan bahasa kedua berturut-turut membuat sistem bahasa, dan sistem-sistem inilah yang diberi nama bahasantara atau interlanguage (Ainin, 2011). Interlanguage merupakan isu utama dalam kajian pemerolehan bahasa kedua atau bahasa sasaran. Dikatakan demikian, karena isu ini berkaitan dengan perkembangan bahasa pembelajar dan isu perkembangan bahasa pembelajar sangat berkaitan dengan proses yang dilakukan oleh pembelajar dalam menguasai bahasa sasaran. Secara tersirat telah dipertegas oleh omaggio, bahwa kiranya kurang lengkap mengkaji bahasa manusia tanpa memperhatikan fenomena bahasa pembelajar (interlanguage) (Fauziati, 2015).

Dari sini dapat dilihat bahwa fitur yang paling menonjol dari interlanguage adalah adanya kesalahan yang umumnya dikenal sebagai kesalahan interlanguage. Penelitian yang dalam tentang kesalahan interlanguage bisa membantu para guru untuk lebih memahami masalah yang dihadapi pembelajar sehingga dapat memberikan pengajaran yang tepat kepada peserta didik. Dengan demikian, mereka dapat mencapai kompetensi yang baik atas bahasa yang mereka pelajari. Ada pun kesalahan interlanguage ini adalah hal yang lumrah terjadi pada setiap pembelajar bahasa. Karena dalam proses menuju penguasaan bahasa sasaran yaitu bahasa Arab pasti akan terjadi beberapa kesalahan di kalangan pembelajar bahasa. Baik dalam hal menerjemahkan bahasa sasaran dengan menggunakan struktur gramatika bahasa ibu(Chaer, 2015). 
ISSN: 2656-9531

JOURNAL OF LANGUAGE, LITERATURE, AND TEACHING

Vol. 1 No. 3, December 2019, pp. $11-23$

DOI:https://doi.org/10.35529/jllte.v1i3.11-23

西测國隆废好学院

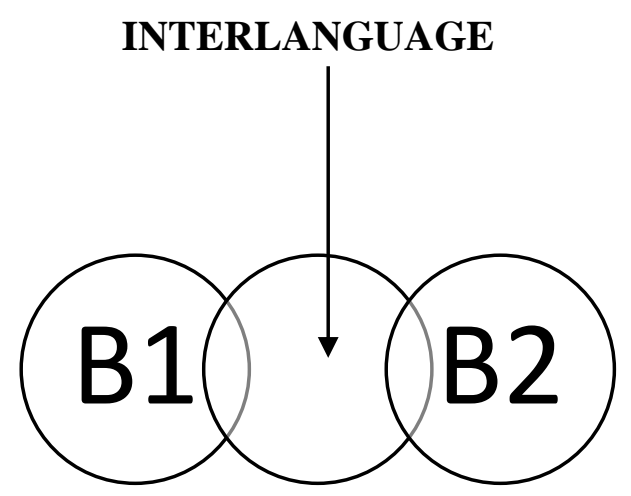

Diantara isu pokok yang berkembang dalam pemerolehan dan pengajaran bahasa kedua (bahasa asing) adalah tentang peranan pemhetahuan gramatika, yang mepunyai anggapan bahwa gramatika merupakan factor utama dalam belajar bahasa kedua (Sa'adah, 2015). Survey universitas al-azhar Indonesia (2007) menjadi bukti kuat bahwa gramatika masih menajdi isu utama dalam pembelajaran bahasa arab di indonesia. Tercatat mayoritar siswa ma $(57,1 \%)$ mendapatkan skor $<5$ untuk pemahaman gramatika.

Isu kedua, beranggapan bahwa balikan yang diberikan oleh guru atau pihak lain yang berkompeten terhadap kesalahan gramatika yang dilakukan oleh pembelajar mereka menguasai bahasa kedua. Pandangan ini beranggapan bahwa dengan memberikan koreksi pada pembelajar setiap kali mereka melakukan kesalahan akan membuat mereka segera menguasai bahasa target secara sempurna(Sa'adah, 2015).

Loda dan I Nyoman Sudiana menyatakan bahwa perbedaan bahasa pertama dan bahasa kedua merupakan sumber utama kesalahan dan kesulitan di dalam belajar bahasa kedua tersebut. Sinyalemen lado ini menghasilkan hipotesis analisis kontrastif yang menyatakan bahwa seorang pembelajar bahasa asing seringkali melakukan "transfer" dari bahasa pertama 


\section{JOURNAL OF LANGUAGE, LITERATURE, AND TEACHING}

Vol. 1 No. 3, December 2019, pp. 11 - 23

DOI:https://doi.org/10.35529/jllte.v1i3.11-23

ke bahasa kedua dalam penggunaan struktur bahasa untuk mengungkapkan gagasan dalam bahasa keduanya (James, 2007).

Richards menyebutkan ada dua jenis kesalahan lain dalam pemerolehan bahasa yaitu kesalahan intralingual dan developmenta(Syahid, 2015). Kesalahan intralingual seperti generalisasi yang salah, penggunaan aturan yang tidak lengkap, dan kegagalan mempelajari syarat-syarat penggunaan aturan. Sedangkan developmental merupakan gambaran usaha pembelajar dalan membangun hipotesa tentang bahasa kedua berdasarkan kompetensi yang terbatas.

Kesalahan intralingual dan developmental berupa kesalahan yang mencerminkan ciriciri umum belajar kaidah, baik kesalahan dalam melakukan generalisasi yang berlebihan, penerapan kaidah yang tidak sempurna, maupun kegagalan pembelajar dalam mempelajari kondisi-kondisi menerapkan kaidah tersebut. Kesalahan ini karena kaidah B2 tidak dimiliki oleh B1 sehingga penerapan kaidah B2 oleh pembelar merupakan kesalahan yang sama dalam penerapan kaidah B1nya(Tarone, 2006).

Melihat dari masalah di atas, Maka peneliti tertarik untuk mengadakan penelitian mengenai fenomena interlanguage yang terjadi pada santri kelas VII hingga kelas IX MTS di pondok pesantren muqimussunnah palembang, mengingat di Pondok Pesantren ini santri wajib munggunakan bahasa Arab atau pun Inggris aktif sebagai bahasa sehari hari. Dan menariknya karena berbahasa adalah wajib bagi santri maka para santri sering kali melakukan kesilapan berbahasa. Para santri seringkali memasukan struktur bahasa ibu ke dalam bahasa sasaran.

\section{METODE}

Metode penelitian yang digunakan pada penelitian ini adalah kualitatif deskriptif untuk memperoleh informasi atau menggambaran suatu hal yang diteliti dan tidak bisa didapatkan dengan cara pengukuran atau statistika, misalnya: ide, persepsi, pendapat dan lain sebagainya (Moloeng, 2014).teknik pengumpulan data menggunakan Observasi mengamati keadaan dan 


\section{JOURNAL OF LANGUAGE, LITERATURE, AND TEACHING}

Vol. 1 No. 3, December 2019, pp. $11-23$

DOI:https://doi.org/10.35529/jllte.v1i3.11-23

situasi pembelajaran baik disekolah maupun diasrama. Wawancara dilakukan kepada ketua bagian bahasa untuk mendapatkan data tentang faktor-faktor terjadinya interlanguage dan dokumentasi merupakan tugas insya siswa yang diperoleh dari guru bahasa arab untuk memperkuat data.

Sedangkan untuk analisis data, yaitu analisis data kualitatif dengan menggunakan model Miles dan Hubbermen yang terdiri dari tiga langkah, yaitu reduksi data, penyajian data, penarikan kesimpulan atau verifikasi (Huberman, 2014). Pertama, analisis data penelitian kualitatif sebagaimana ditulis Malik diartikan sebagai proses pemilihan, pemusatan perhatian pada penyederhanaan, pengabstakan, dan transformasi data "kasar" yang muncul dari catatancatatan tertulis di lapangan. Pertama, Pada penelitian ini kami mencatat terlebih dahulu hasil observasi dan wawancara dalam bentuk ringkasan, kemudian kita memilah dan memilih data yang sesuai dengan apa yang kita butuhkan. Kedua, penyajian data Pada tahap ini peneliti banyak terlibat dalam kegiatan penyajian atau penampilan (display) dari data yang dikumpulkan dan dianalisis sebelumnya. Dalam penelitian ini peneliti menyajikan data berupa table . ketiga, Verifikasi Seperti yang dijelaskan di atas bahwa kesimpulan awal yang dikemukakan masih bersifat sementara dan akan berubah bila ditemukan bukti-bukti buat yang mendukung tahap pengumpulan data berikutnya. Proses untuk mendapatkan bukti-bukti inilah yang disebut sebagai verifikasi data. Apabila kesimpulan yang dikemukakan pada tahap awal didukung oleh bukti-bukti yang kuat dalam arti konsisten dengan kondisi yang ditemukan saat peneliti kembali ke lapangan maka kesimpulan yang diperoleh merupakan kesimpulan yang kredibel.

\section{HASIL}

Dalam belajar bahasa kedua seringkali melakukan kesalahan berbahasa. Brown menyebutkan bahwa kesalahan dapat terjadi karena: Transfer antarbahasa yakni pemindahan unsur bahasa pertama (B1) yang telah memfosil ke dalam B2 (bahasa yang sedang dipelajari). kesalahan Overgeneralisasi (penyamarataan), dan kesalahan konteks pembelajaran, yaitu 


\section{JOURNAL OF LANGUAGE, LITERATURE, AND TEACHING}

Vol. 1 No. 3, December 2019, pp. 11 - 23

DOI:https://doi.org/10.35529/jllte.v1i3.11-23

kesalahan yang disebabkan oleh metode, materi, cara mengajar dosen/guru yang salah, Kesalahan karena strategi belajar B2 sebagai akibat dari pendekatan yang dilakukan oleh pembelajar terhadap materi "kaidah B2" yang sedang dipelajari (strategies of second language learning).

1. Transfer bahasa

Yang dimaksud dengan transfer bahasa adalah bahwa butir-butir atau kaidah-kaidah yang terjadi dalam performasi interlanguange dipengaruhi oleh kaidah-kaidah asli atau bahasa pertama. Dengan kata lain transfer bahasa merupakan suatu proses yang bersumber dari adanya interferensi bahasa pertama dan proses ini terjadi karena pembelajar mentransfer aturan-aturan bahasa aslinya ke dalam bahasa sasaran yang dihasilkan(Skehan, 2008). Adapun bentuk-bentuk kesalahan yang dilakukan oleh siswi pondok pesantren muqimussunnah sebagai berikut:

Tabel. 1 Kesalahan Proses Transfer Bahasa

\begin{tabular}{|c|c|c|c|}
\hline No & Kesalahan transfer bahasa & Bahasa indonesia & Bahasa arab \\
\hline 1 & 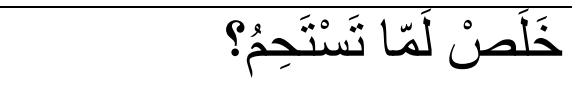 & $\begin{array}{lll}\text { apakah kamu sudah } \\
\text { mandi? }\end{array}$ & 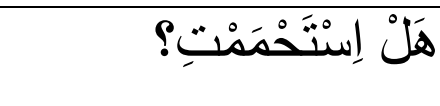 \\
\hline 2 & ل ل ماذا ماذا & tidak apa-apa & \\
\hline 3 & أَنَا تَنْتَطِبحَ صغير صغير & aku bisa sedikit-sedikit & قَلَاْْنَ \\
\hline 4 & 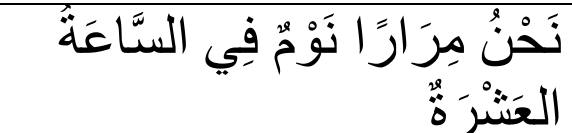 & $\begin{array}{l}\text { kami selalu tidur pukul } \\
12 \text { malam }\end{array}$ & 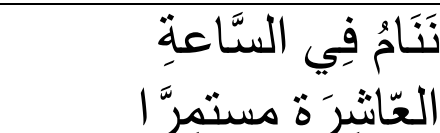 \\
\hline 5 & انت الأن تسكن أين؟ & $\begin{array}{l}\text { Kamu sekarang tinggal } \\
\text { dimana? }\end{array}$ & كن الآن? \\
\hline
\end{tabular}

Beberapa contoh diatas merupakan kesalahan gramatikal yang berbentuk transfer bahasa, yang mana siswa masih menggunakan kaidah bahasa pertama atau bahasa Indonesia untuk mengucapkan bahasa arab. untuk pembelajar bahasa kedua yang belum mengetahui 


\section{JOURNAL OF LANGUAGE, LITERATURE, AND TEACHING}

Vol. 1 No. 3, December 2019, pp. 11 - 23

DOI:https://doi.org/10.35529/jllte.v1i3.11-23

kaidah bahasa kedua atau yang belum mempunyai kompetensi gramatikal bahasa kedua maka hal ini akan terjadi dalam proses belajar bahasa kedua.

\section{Overgeneralisasi}

Proses yang ketiga adalah penyemarataan yang berlebihan atau yang terkenal dengan istilah overgeneralisasi. Istilah overgeneralisasi mengacu pada penyamarataan yang berlebihan terhadap kaidah-kaidah bahasa sasaran tanpa memperhatikan pengecualian yang ada. Baradja mengemukakan overgeneralisasi sebagai kecendrungan untuk mengindahkan adanya pengecualian yang terdapat pada aturan bahasa(Ainin, 2011).

\section{Tabel. 2 Proses Kesalahan Overgeneralisasi}

\begin{tabular}{|c|c|c|}
\hline No & Kesalahan overgeneralisasi & Bahasa arab \\
\hline 1 & سافر فيصل إلى مكةِ & سافر فيصل إلى مكةً \\
\hline 2 & جائت أمي من المكةِ & جائت أمي من المكةُ \\
\hline
\end{tabular}

Pada tabel diatas merupakan bentuk proses kesalahan pada overgeneralisasi yang mana siswa melakukan penyamarataan pada kaidah belajar bahasa arab, dari hasil yang kami teliti kesalahan ini merupakan bentuk kesalahan dikarenakan kurangnya kompetensi siswa dalam memahami kaidah bahasa arab, sehingga siswa melakukan penyamarataan dalam kaidah yang tidak mereka ketahui.

\section{Strategi belajar bahasa kedua}

Yang dimaksud dengan strategi belajar bahasa kedua sebagaimana diungkapkan oleh Baradja adalah mengacu pada suatu kecendrungan pembelajar untuk menyederhanakan sistem bahasa sasaran. Bagi pembelajar bahasa Arab sebagai bahasa asing terutama tahap pemula juga cendrung menghilangkan unsur penanda jamak pada kata kerja yang pronominanya berbeda jamak dan menghilangkan unsur penanda muannats pasa kata sifat yang mausufnya berupa muannats. 
JOURNAL OF LANGUAGE, LITERATURE, AND TEACHING

Vol. 1 No. 3, December 2019, pp. 11 - 23

DOI:https://doi.org/10.35529/jllte.v1i3.11-23

Tabel. 3 Proses Kesalahan Strategi Belajar Bahasa Kedua

\begin{tabular}{|c|c|c|c|}
\hline No & $\begin{array}{l}\text { Kesalahan strategi } \quad \text { belajar } \\
\text { bahasa kedua }\end{array}$ & Bahasa Indonesia & Bahasa arab \\
\hline 1 & 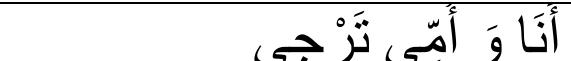 & aku dan ibuku pulang & \\
\hline 2 & 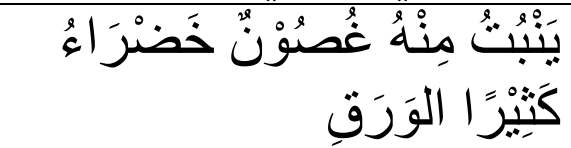 & $\begin{array}{l}\text { dari pohon itu tumbuh } \\
\text { dahan yang berwarna hijau } \\
\text { dan bedaun }\end{array}$ & خَضَرَ اعُ \\
\hline 3 & 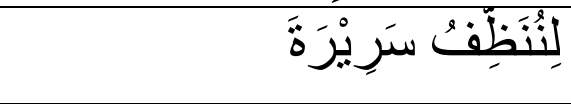 & $\begin{array}{ll}\text { untuk } & \text { membereskan } \\
\text { ranajng }\end{array}$ & لِنْنَظِفَتَ السَّرِيْرَةَ \\
\hline 4 & وِسَادَتَنِ صَغَغِيْرَةُ & dua bantal kecil & وِسَادَتَانِ صَغِيْرَنَانِ \\
\hline 5 & نَلْعَبُ بِقَلَبِ فَرْهَة & $\begin{array}{l}\text { kami bermain dengan hati } \\
\text { senang }\end{array}$ & 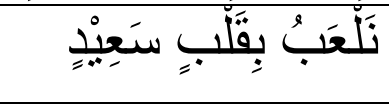 \\
\hline
\end{tabular}

Pada tabel diatas merupakan bentuk proses kesalahan siswa pada strategi belajar bahasa kedua yang mana siswa melakukan kesalahan dalam memasukkan domir ketika berbicara bahasa arab, akan tetapi dalam penulisan siswa cenderung teliti dalam menggunakan domir. Sebagaimana yang kami teliti ini merupakan kekeliriun bukan kesilapan yaitu siswa sudah pernah belajar tentang penggunaan domir sehingga siswa sudah mempunyai kompetensi.

\section{PEMBAHASAN}

Selama pengguna bahasa masih dalam proses pemerolehan dan pembelajaran bahasa, maka kesalahan-kesalahan berbahasa masih tetap terjadi atau tanpa sengaja dilakukannya. Kesalahan berbahasa tidak hanya terjadi pada pembelajar yang mempelajari Bahasa Asing, tetapi juga terjadi pada pembelajar yang mempelajari bahasa sumbernya sendiri.

Analisis kesalahan berbahasa adalah prosedur lanjutan dari analisis kontrastif, yaitu prosedur yang dilakukan adalah mempelajari, meneliti, dan menela'ah kesalahan pembelajar yang sedang mempelajari bahasa asing(Fauziati, 2015). Karena dalam proses belajar bahasa asing sangat mungkin ditemukan kesalahan. Grammar memiliki pengertian sebagai uraian dan 


\section{JOURNAL OF LANGUAGE, LITERATURE, AND TEACHING}

Vol. 1 No. 3, December 2019, pp. 11 - 23

DOI:https://doi.org/10.35529/jllte.v1i3.11-23

aturan dari struktur suatu bahasa dimana satuan-satuan linguistik seperti kata atau frase digabung untuk menghasilkan kalimat dalam bahasa tersebut yang harus dipahami oleh kelompok penggunanya.

Beberapa contoh akan memperjelas pernyataan tersebut. Pertama, ada penelitian tentang pemerolehan bahasa pada bayi, yang baru-baru ini dilontarkan (Brown, 1994). Slobin memberi nama sebuah antologi penelitian tersebut dengan nama The Ontogenesis of Grammar. Sejak anak membuat kemajuan dari sama sekali tidak memiliki pengetahuan tentang bahasa lisan sampai pada tahap penguasaan yang memadai pada usia lima tahun, dan sejak hanya satu bahasa yang dikuasai, pada hakikatnya kajian tentang bahasa anak tidak lagi dibicarakan sebagai sebuah bentuk kajian Bahasa Antara. Tetapi kajian tentang bahasa kedua atau pemelajaran bahasa asing terkait dengan proses seseorang dari ekabahasawan (monolingual) menjadi dwibahasawan (bilingual). Dalam hal ini ada 2 (dua) bahasa yang dilibatkan dalam proses pemelajaran yaitu L1 dan L2(Fauziati, 2011).

Ada dua pendapat yang muncul dalam menyikapi terjadinya kesalahan-kesalahan dalam proses pembelajaran bahasa kedua atau asing. Pendapat pertama datang dari kalangan Behavioris yang menganggapnya sebagai sesuatu yang buruk sehingga harus dihindari sebisa mungkin. Kesalahan menunjukkan kegagalan pembelajar untuk belajar kaidah bahasa secara benar, atau kegagalan pengajar karena tidak mampu menyampaikan maksudnya secara jelas atau tidak memberikan latihan-latihan yang cukup terhadap materi yang telah diajarkan. Oleh karena itu, kesalahan-kesalahan ini harus diatasi dengan memberikan banyak latihan disertai dengan contoh-contoh yang benar(Goad \& White, 2006).

Brook memandangnya sebagai sebuah "dosa" yang seharusnya tidak terjadi dan pengaruhnya harus dibatasi, meskipun kemunculannya memang tidak bisa dihindari. Sudiana menganggapya sebagai "penyakit" pembelajar bahasa kedua yang harus disembuhkan melalui terapi. Munculnya kesalahan-kesalahan juga menunjukkan bahwa pengajaran bahasa belum berhasil sebagai akibat dari metode dan teknik yang tidak memadai. Sementara itu, secara lebih halus, George menyebutnya sebagai "bentuk yang tidak diinginkan. Dengan kata lain, 


\section{JOURNAL OF LANGUAGE, LITERATURE, AND TEACHING}

Vol. 1 No. 3, December 2019, pp. 11 - 23

DOI:https://doi.org/10.35529/jllte.v1i3.11-23

pembelajar bahasa -menurut kaum Behavioris- tidak boleh melakukan kesalahan karena kesalahan hanya akan menjadi penghambat dalam proses penguasaan terhadap bahasa target(Ahmadi, 2014).

Pendapat kedua datang dari kalangan Mentalis, yang memandang kesalahan secara lebih positif. Kesalahan dalam pembelajaran bahasa kedua adalah sesuatu yang wajar, bahkan memiliki peranan penting karena bisa menjadi sumber yang kaya bagi para ahli bahasa. Kesalahan juga menjadi bagian penting dalam proses pembelajaran karena mencerminkan tingkat perkembangan bahasa pembelajar dengan ciri dan gramatika yang khas. Brown dan Selinker bahkan memandang kesalahan ini sebagai suatu bentuk strategi belajar hasil yang lebih baik(Larry, 1997).

Sementara itu, Krashen dan Terrel menganggap bahwa kesalahan dalam belajar bahasa kedua adalah suatu bentuk usaha pembelajar untuk "mengisi sesuatu yang kosong", yaitu adanya suatu unsur/struktur bahasa target yang belum diketahui atau dikuasainya sewaktu menggunakan bahasa tersebut, sehingga dia menggunakan unsur/struktur bahasa pertama atau yang menyerupainya. Teori ini kemudian dinamakan "monitor". Oleh karena itu, guru seyogyanya menghargai usaha pembelajar dan menolong seperlunya, bukan memandangnya sebagai sesuatu yang negative(Bernhardt \& Krashen, 1989).

Dari berbagai pendapat di atas, dapat disimpulkan bahwa kesalahan adalah sesuatu yang sangat wajar dilakukan dalam proses penguasaan bahasa kedua/asing, baik oleh pembelajar dewasa maupun anak-anak. Kesalahan tidak perlu ditakuti karena tidak seorangpun bisa terbebas darinya meskipun telah dilakukan segala usaha untuk mencegahnya. Dengan kata lain, kesalahan adalah bagian integral dalam proses belajar bahasa sampai si pembelajar benar-benar

menguasainya dengan sempurna.

Namun demikian, tidak berarti bahwa setiap kesalahan yang muncul dapat dibiarkan begitu saja tanpa ada perhatian dan usaha perbaikan, terlebih jika kesalahan yang sama terus terulang dalam waktu yang cukup lama. Kesalahan sama yang terus menerus dilakukan dan 
ISSN: 2656-9531

JOURNAL OF LANGUAGE, LITERATURE, AND TEACHING

Vol. 1 No. 3, December 2019, pp. 11 - 23

DOI:https://doi.org/10.35529/jllte.v1i3.11-23

tidak juga menunjukkan adanya perkembangan yang signifikan menunjukkan adanya kegagalan dalam proses pembelajaran, baik karena faktor pengajar dengan sistem pembelajaran yang diterapkannya, maupun karena faktor pembelajar bahasa itu sendiri dengan keterbatasan kemampuannya atau cara belajar yang digunakannya.

\section{REFERENSI}

Ahmadi, A. (2014). Analisis Kontrastif Dan Analisis Kesalahan Dalam Pembelajaran Bahasa Arab Sebagai Second Language. At-Tajdid: Jurnal Ilmu Tarbiyah.

Ainin, M. (2011). Analisa Bahasa (Pembelajaran Bahasa Arab Sebagai Bahasa Asing) (Amal, Ed.). Malang: Misykat Indonesia.

Bernhardt, E. B., \& Krashen, S. D. (1989). Second Language Acquisition And Second Language Learning. The Modern Language Journal. Https://Doi.Org/10.2307/326882

Brown. (1994). Principles Of Language Learning And Teaching (P. Hall, Ed.). New Jersey. Chaer, A. (2015). Psikolinguistik. Jakarta: Pt Rineka Cipta.

Fauziati, E. (2011). Interlanguage And Error Fossilization: A Study Of Indonesian Students Learning English As A Foreign Language. Indonesian Journal Of Applied Linguistics. Https://Doi.Org/10.17509/Ijal.V1i1.97

Fauziati, E. (2015). Strategi Belajar Yang Tercermin Dalam Kesalahan Interlanguage Siswa Man 1 Surakarta. Jurnal Penelitian Humaniora, 16.

Fauziati, E., \& Maftuhin, M. (2016). Interlanguage Verb Tense Systems Of Indonesian Efl Learners. Journal of Foreign Languages, Cultures And Civilizations. Https://Doi.Org/10.15640/Jflcc.V4n2a7

Goad, H., \& White, L. (2006). Ultimate Attainment In Interlanguage Grammars: A Prosodic Approach. Second Language Research. Https://Doi.Org/10.1191/0267658306sr268oa

Huberman. (2014). Qualitative Data Analysis, A Methods Sourcebook, Edition Usa: Sage Publications. Terjemahan Tjetjep Rohindi Rohidi. Jakarta: Ui-Press.

James, M. A. (2007). Interlanguage Variation And Transfer Of Learning. Iral - International Review Of Applied Linguistics In Language Teaching. 
ISSN: 2656-9531

\section{JOURNAL OF LANGUAGE, LITERATURE, AND TEACHING}

Vol. 1 No. 3, December 2019, pp. 11 - 23

DOI:https://doi.org/10.35529/jllte.v1i3.11-23

Https://Doi.Org/10.1515/Iral.2007.004

Larry, S. (1997). Rediscovering Interlanguange. London: Longman.

Moloeng, Lexi J. (2014). Metode Penelitian Kualitatif. Bandung: Pt Remaja Rosdakrya.

Sa'adah, F. (2015). Analisis Kesalahan Berbahasa Dan Peranannya Dalam Pembelajaran Bahasa Asing. 1-29.

Skehan, P. (2008). Interlanguage And Language Transfer. In The Handbook Of Educational Linguistics. Https://Doi.Org/10.1002/9780470694138.Ch29

Syahid, A. H. (2015). Bahasa Arab Sebagai Bahasa Kedua (Kajian Teoretis Pemerolehan Bahasa Arab Pada Siswa Non-Native). Arabiyat: Jurnal Pendidikan Bahasa Arab Dan Kebahasaaraban. Https://Doi.Org/10.15408/A.V2i1.1797

Tarone, E. (2006). The Interlanguage Hypothesis. Science Direct. 